\title{
The status Quo and Training Strategies of Poor College Students' Employability
}

\author{
Hongxiu $\operatorname{Tan}^{1, a}$ \\ ${ }^{1}$ Shaoguan university,Education School, Guangdong Shaoguan, 512005 China \\ a937090013@qq.com
}

\begin{abstract}
Keywords: poor college student; employability; training strategies
Abstract. China is a country with a vast territory and great regional variance. There is a definite gap between rural and urban areas in terms of education level, economic development and literacy. The biggest wish of poor families is that their children can receive a good education and find a stable job after graduation. Employment has always been vital to people' s livelihood in China and a major problem hindering the harmonious development of Chinese society. Poor college students are in a weak position in the job market. Their ideas, psychology, quality and other factors influence the steady development of their employability. Therefore, it is all the more urgent to study training strategies of poor college students' employability.
\end{abstract}

\section{Introduction}

The employment of poor college students has always been a hot topic perplexing the education sector. Whether the employment of poor college students can be properly solved has a direct impact on the harmony of Chinese society and development of ethnic groups. In recent years, China has made a lot of efforts to bridge the gap between urban and rural areas. It gradually improves the employment of poor college students, provides more job opportunities for poor college students, implements employment assistance plans for poor college students actively, increases the employment rate of poor college students fundamentally and offers basic guarantee to the harmonious development of society and colleges.

The Status Quo of Poor College Students’ Employability

The radiating area of Guangdong Province is large. Every year a large number of students are enrolled from in and around the area. Therefore, the absolute number of poor college students is getting larger and larger. This is very unfavorable to the shortening of the gap between urban and rural areas and also causes great obstacles to social and economic development. To understand the status quo of poor college students' employability in current stage in China, the author analyzes several Universities of Guangdong Province in the three months before graduate. The analysis results of specific data are shown in Tables 1 and 2. Table 1 shows the distribution of poor college students in University of Guangdong. Table 2 shows the employment of poor college students in University of Guangdong.

From Table 1, we know that the proportion of poor college students in University of Guangdong Province is very high. There are also some extraordinarily poor students and only a small portion of ordinary students. From Table 2, we can see that the employment rate in University of Guangdong Province is very low. Only $24.0 \%$ of college students can succeed in finding a job. The employment rate is very low in any region. Besides, poor college students have very bad family conditions. They hardly have any extra resources to support them to pursue advanced studies. So there are very few poor college students (only 6.4\%) pursuing advanced studies. Most of the poor college students fail to find a job in the three months before graduate., which makes the hope of poor families that their children can go out fall through [1]. 
Table 1: The Distribution of Poor College Students (\%)

\begin{tabular}{ccccccccc}
\hline \multicolumn{3}{c}{ Rural Students } & \multicolumn{3}{c}{$\begin{array}{c}\text { Minority Region } \\
\text { Students }\end{array}$} & \multicolumn{3}{c}{ Ordinary Students } \\
\hline PS & EP & OS & EP & PS & EP & EP & PS & EP \\
& S & & S & & S & S & S \\
55 & 25 & 20 & 63 & 22 & 15 & 19 & $8 \%$ & 73 \\
$\%$ & $\%$ & $\%$ & $\%$ & $\%$ & $\%$ & $\%$ & & $\%$ \\
\hline
\end{tabular}

(Note: PS= poor students, EPS= extraordinarily poor students, OS= ordinary students )

Table 2: The Employment of Poor College Students (\%)

\begin{tabular}{ccc}
\hline Employment & $\begin{array}{c}\text { Pursuing } \\
\text { Advanced Studies }\end{array}$ & Unemployment \\
\hline $24.0 \%$ & $6.4 \%$ & $69.6 \%$ \\
\hline
\end{tabular}

\section{Problems with the Enhancement of Poor College Students’ Employability}

Why is there a fry cry between the employment rate of poor college students and that of ordinary students, although they receive the same professional education? To figure out this problem, the author conducted a questionnaire survey on existing problems with poor college students' employability. The author selected 1,000 students randomly to complete the questionnaire, including 264 poor students, to ensure the accuracy and representativeness of questionnaire survey. The analysis results of specific data are shown in Table 3:

Table 3: Existing Problems with Poor College Students’ Employability (\%)

Psychological Problems

Psychological Ability Social

Problems $\quad$ Problems $\quad$ Problems

$31.4 \% \quad 25.7 \% \quad 42.9 \%$

The growth environment of poor college students was quite different from that of urban students. Long-term poverty made them develop a serious inferiority complex. With the passage of time, such kind of inferiority complex would develop into a passive personality and greatly reduced poor college students' employability. Under normal circumstances, the "unhealthy psychology" of poor college students would be manifested in five aspects: low self-esteem, anxiety, insecurity, defensiveness and jealousy [2]. If such an "unhealthy psychology" of poor college students cannot be reconciled, poor college students' employability would be lower and lower. This ranked second in the psychological problems in question and accounted for $31.4 \%$ of the total population.

Ability Problems

Employability was a major channel to improve the employment rate of poor college students and a comprehensive ability developed in ongoing practice and exploration. Influenced by family factors, most of the poor college students didn't receive specialized education in music, art or other subjects before going to college. As a result, their humanistic quality was generally not high. They didn't have any expertise and lack competitive advantages. On the other hand, poor college students were generally introverted and not good at communicating with people. Such kind of characters will result in poor team spirit and lack of cooperation between students and teachers. Students can't give full play to their caliber at work and didn't have the capability to sell themselves.

\section{Social Problems}

The highest percentage (42.9\%) in this survey was on social problems. Social problems were also objective problems with the employment of poor college students. With the increase of employment competitions, the job market provided fewer and fewer jobs for poor college students. Coupled with inadequate employability of poor college students, the status quo of poor college students' employment was getting worse. On the other hand, many enterprises showed preference to a permanent urban residence permit in recruitment. Under the same competitive conditions, poor 
college students didn’t have employment advantages, but faced with higher employment difficulty [3].

\section{Training Strategies of Poor College Students' Employability}

To build a psychological education system for poor college students

Colleges should focus on the psychological health education of students, alleviate the psychological burden of poor college students and let teachers help them build confidence and hold their heads high to face all kinds of pressures in society. Besides, for graduated poor college students, colleges must offer certain help, provide as many job opportunities for them as possible, take the initiative to explain all kinds of psychological problems that they will meet in society after leaving school and show concern and support to them as a mentor and a friend, to make them face the society with a good mindset [4].

To promote the enhancement of poor college students' employability

Colleges must give lectures on college students' employment regularly, help poor college students spontaneously, guide them to pinpoint their employment goals, develop career plans rationally and train them specifically. In addition, colleges must build a student skill training system, ensure that students can master professional techniques and provide basic guarantee for their employment. Strengthen negotiation with relevant guarantee departments, enable enterprises to provide professional skill trainings for poor college students for free, help them obtain professional practicing certificates, solve the delinking between their theory and practice, further enhance the advantages of poor college students in competitions and help them find jobs.

\section{Conclusion}

From the above analysis, the present study analyzes the status quo of poor college students' employability in University of Guangdong, understands problems with the enhancement of their employability, develops training strategies specifically, strengthen the government's emphasis on poor college students, provide them with more job opportunities, offer help and support in various aspects and provide basic guarantee for the employment of poor college students.

\section{Acknowledgements}

This work was supported by Guangdong Province education and scientific research "Twelfth Five-Year Plan" 2013 Annual Research Project (2013JK160) "An Empirical Study of Poor College Students' Psychological capital and employability".

\section{References}

[1]Jin Xin. The Empirical Research on the Construct and the Status Quo of Contemporary College Students' Employability[J]. Journal of Northeast Normal University, 2012(6):237-240.

[2]ZhaoYan-gang, Wang Zhi-chen. Strategies for the Improvement of the College Students' Employability:Taking Shijiazhuang Tiedao University as an Example[J]. Journal of Shijiazhuang Tiedao University, 2014(4):101-105.

[3]Ding Fang-sheng. Current Situation and Improving Strategies of College Students' Moral Identity[J]. Journal of Zhejiang Ocean University, 2014,31(2):56-60.

[4]Martinez-Roca C, Martinez M, Pineda P. The role of Career Guidance in the Development of Competences for Socially fair Employability[J]. Procedia - Social and Behavioral Sciences, 2014, 139:343-350.

[5]Lindgren M, Packendorff J, Sergi V. Thrilled by the discourse, suffering through the experience: Emotions in project-based work[J].Human Relations, 2014, 67(11):1383-1412. 